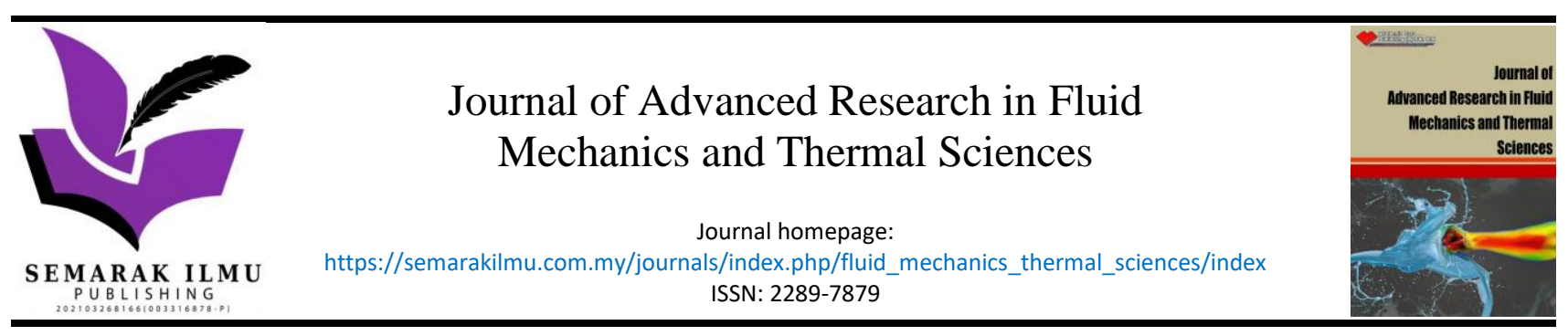

\title{
Effect of Electrode Plates on the Engine Performance and Gas Emissions of a Four-Stroke Petrol Engine
}

\author{
Mat Sazilin Ayub ${ }^{1}$, Siti Nurul Akmal Yusof ${ }^{2,}{ }^{*}$, Saiful Bahri Mohamed ${ }^{2, *}$, Mohd Sani Said ${ }^{3}$, Yutaka \\ Asako ${ }^{4}$, Nor Azwadi Che Sidik ${ }^{4}$, Mohd Shahir Kasim ${ }^{5}$, Ahmad Tajuddin Mohamad ${ }^{4}$ \\ Kolej Komuniti Besut, Tingkat 3, Bangunan Baitul Ehsan, Jalan Besar, 22000 Jerteh, Terengganu, Malaysia \\ Faculty of Innovative Design and Technology, Universiti Sultan Zainal Abidin, 21300 Terengganu, Malaysia \\ Department of Polytechnic Education, Politeknik Kota Bharu, KM24, Kok Lanas, 16450 Ketereh, Kelantan, Malaysia \\ 4 Department of Mechanical Precision Engineering, Malaysia-Japan International Institute of Technology, Universiti Teknologi Malaysia, Jalan \\ Sultan Yahya Petra, 54100 Kuala Lumpur, Malaysia \\ 5 Faculty of Manufacturing Engineering, Universiti Teknikal Malaysia Melaka, Jalan Hang Tuah Jaya, 76100 Durian Tunggal, Melaka, Malaysia
}

\section{ARTICLE INFO}

\section{Article history:}

Received 2 August 2021

Received in revised form 8 December 2021

Accepted 10 December 2021

Available online 4 January 2022

\section{Keywords:}

Alternative fuel; HHO gas; electrode plates; water electrolysis; engine performance

\section{ABSTRACT}

The effectiveness generation of $\mathrm{HHO}$ gas depends on the characteristic of the electrode plates. This research aims to investigate the effect of the HHO gas generator produced through the water electrolysis technique. The effect of several controlled factors, such as the number, distance, and area of electrode plates used in the water electrolysis process to produce $\mathrm{HHO}$ gas, were studied and analyzed using a factorial full design approach (RBFAD). Stainless Steel of $1 \mathrm{~mm}$ thickness has been chosen as an electrode plate material. A single-cylinder four-stroke S.I. engine was used as the test engine. The engine was tested at 16 different setups where the engine speed and exhaust emission of carbon monoxide (CO) and hydrocarbon ( $\mathrm{HC})$ gasses were recorded. The statistical significance of these controlled factors contributing to the engine performance and exhaust emission has been established with the analysis of variance. It was found that the number of plates that interacted with a large area of electrode plate is a significant factor that caused an increase in engine speed on an average of $26 \%$, an average reduction in CO by $43 \%$, and a decrease in $\mathrm{HC}$ gas by $42 \%$. In conclusion, the higher number of electrode plates and a higher electrode plate area produced more $\mathrm{HHO}$ gas that yields completed internal combustion. Thus, it can enhance the engine speed and reduces the $\mathrm{CO}$ and $\mathrm{HC}$ gas content in exhaust emissions.

\section{Introduction}

The alarming level of air pollution and increasing petrol price are the two major factors in transportation industries that have motivated the researchers to look for the alternative solution. Scientists from the Intergovernmental Panel on Climate Change recently predicted that global surface

\footnotetext{
* Corresponding author.

E-mail address: snakmalyusof@unisza.edu.my

* Corresponding author.

E-mail address: saifulbahri@unisza.edu.my
}

https://doi.org/10.37934/arfmts.90.2.90108 
temperatures would begin to increase by $1.4-5.8^{\circ} \mathrm{C}$ by 2100 [1]. The main contributors to greenhouse effects are carbon dioxide $\left(\mathrm{CO}_{2}\right)$, water vapor, methane $\left(\mathrm{CH}_{4}\right)$, Sulphur dioxide $\left(\mathrm{SO}_{2}\right)$, chlorofluorocarbons, and nitrogen dioxide (NOx). Many studies have focused on developing a wide range of renewable energy technologies, such as oxygenated fuels, biofuel ( $n$-butanol), fuel cell, and solar technologies, on lowering fossil fuel consumption and regulating greenhouse gas (GHG) emissions to the environment [2,3]. Reducing $\mathrm{CO}_{2}$ emissions is one of the most effective strategies for reducing GHG emissions [4-6]. Other than $\mathrm{CO}_{2}$, the manufacture and combustion of transportation fuels emit $\mathrm{CH}_{4}$ and nitrous oxide $\left(\mathrm{N}_{2} \mathrm{O}\right)$, contributing to $\mathrm{GHG}$ emissions. Other than using clean fuel alternatives, novel automotive engines with post-combustion emission control devices should be developed to reduce GHG emissions and improve the efficiency of energy systems [7-9]. The use of biodiesel engines in transportation and power generation has progressed in recent decades. The most recent research development trend focuses on developing a novel ICE with low emissions, energy savings, and high-efficiency performance [10]. However, biodiesel fuels have their respective limitations in producing a higher NOx, which leads to poor combustion performance [9]. Thus, to overcome this limitation, using other alternative fuels like hydrogen to fuel IC engines is gaining more attention to enhance the engine speed performance and reduce air pollution $[11,12]$.

$\mathrm{HHO}$, also known as hydroxy or Browns Gas, is a gas created by electrolysis by separating water into hydrogen and oxygen, allowing the gas to remain premixed and used on-demand without the need for storage. It is a promising method of producing hydrogen from renewable sources. The pioneer researcher who studied it was Brown [13], who explored the welding application of the gas. Compared to other alternative fuels, hydrogen has good combustion properties, making it the cleanest fuel for ICEs and has high combustion efficiency [14]. Hydrogen is a flammable gas that is scentless, bland, and colorless in nature. It is known as a diatomic molecule, $\mathrm{H}_{2}$. Hydrogen is the lightest chemical substance in the world, as well as the most abundant. The diffusion coefficient of hydrogen is ten times gasoline, resulting in greater in-cylinder charge homogeneity [15]. Kazim et al., [16] studied the effect of $\mathrm{HHO}$ gas in a small capacity diesel engine. They concluded that adding $\mathrm{HHO}$ and diesel in a small capacity diesel engine significantly improved all engine performance factors. The minimum percentage increases in the combustion efficiency were $2.5 \%$ and $10.5 \%$ for $\mathrm{H} 6$ and $\mathrm{H} 10$, while the minimum increases in torque were $8 \%$ and $15 \%$, respectively. $\mathrm{HHO}$ gas was also used as a supplementary fuel in the internal combustion engine without any modification [17]. HHO does not have a predefined burning temperature where it reacts to the substances when burned. HHO would begin imploding rather than exploding since it mainly contains hydrogen (66.67\%) and oxygen (33.33\%). Furthermore, when $\mathrm{HHO}$ is combined with diesel or gasoline, it can significantly improve the burning efficiency. The flame propagation of $\mathrm{HHO}$ gas is faster than that of standard liquid fuel because hydrogen possesses a fast-burning velocity [18].

The direct production of $\mathrm{H}_{2}$ and $\mathrm{O}$ gas by electrolysis method is straightforward by using the existing energy on the vehicle that is battery [19]. Several authors have studied this in the literature. Shivaprasad et al., [20], in their study, agreed that $\mathrm{H}_{2}$ is considered one of the superior alternative fuels for the $\mathrm{SI}$ engines. This is due to the particular and most desirable characteristics, such as wide flammability range, higher diffusivity, high flame speed, lower ignition energy, etc. [21,22]. Similar work was also carried out by Falahat et al., [23]. The thermal brake efficiency improves after hydrogen enrichment, reaching a peak of about 23\%, thanks to hydrogen's wide flammability and fast flame pace. Recently, Aydin and Kenanoğlu [24] discovered that injecting HHO into the intake manifold of a four-cylinder engine improved the maximum torque and maximum power by $19.1 \%$ and $27 \%$, respectively. While in contrast, specific fuel consumption (SFC) decreased by $14 \%$. However, a complete search of the literature revealed no previous research that focuses on the influencing factors of water electrolysis that affect the production of this hydrogen-rich gas. This is 
the motivation of the present study to conduct an experiment on the three controlled factors of electrode plates which is also one of the significant factors that affect producing hydrogen gas.

This research aims to study engine performance and gas emissions by investigating the effect of the $\mathrm{HHO}$ gas generator produced through the electrolysis technique. Several controlled factors used in the electrolysis process to produce $\mathrm{HHO}$ gas were studied and analyzed using experimental design methods to see the effect on engine speed and pollution produced.

\section{Experimental Setup and Test Procedure}

\subsection{Experimental Description}

A single-cylinder four-stroke $\mathrm{SI}$ engine was used as the test engine. The schematic of the experiment setup is shown in Figure 1. Table 1 shows the specifications of the test engine. The properties of hydrogen and gasoline are shown in Table 2 . The engine was powered by an electric motor, and some minor physical modifications are needed to allow the HHO portion to be routed through the engine inlet port. A special-purpose electronic device was designed and fabricated to supply a constant 10-Amp 18-Volt direct current to each electrode plate for creating electrolysis phenomena. To observe the engine's power output in terms of engine rotation speed and exhaust gas emissions, the effect of controlled factors, which are area, numbers, and distance between electrode plates on the $\mathrm{HHO}$ gas generator, was investigated. A further result of the interaction of control factors and essential factors contributing to hydrogen and oxygen gas development and the speed and release of pollutant gas is also studied.

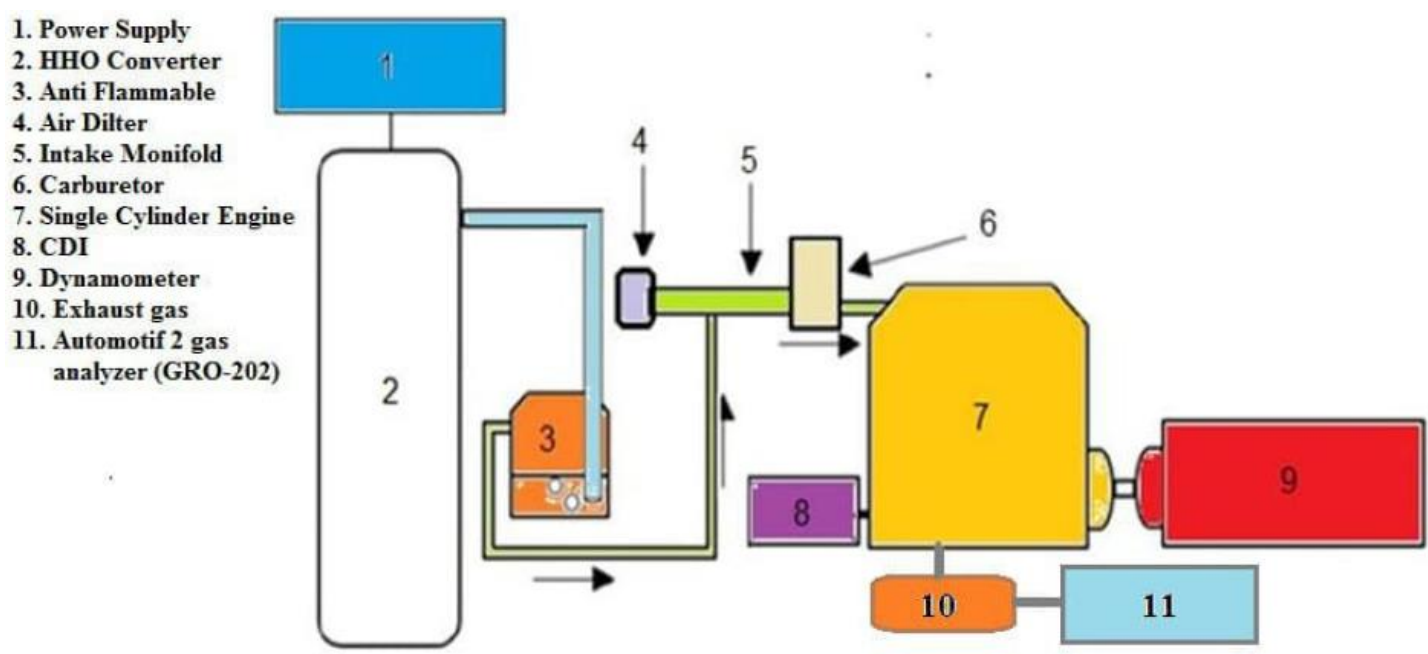

Fig. 1. Experimental test preparation scheme involving a test band engine and a hydroxy gas generator

Table 1

Engine Specifications

\begin{tabular}{ll}
\hline Engine type & Four strokes, single-cylinder \\
\hline Fuel type & Petrol \\
Cooling system & Water-cooled \\
Size $(D \times$ L) & $87 \mathrm{~mm} \times 66 \mathrm{~mm}$ \\
Power & $5 \mathrm{KW}$ at $3000 \mathrm{~min}^{-1}$ \\
Dimension & $500 \times 345 \times 310 \mathrm{~mm}$ \\
Weight & $34 \mathrm{~kg}$ \\
\hline
\end{tabular}


Table 2

The properties of hydrogen and gasoline [25]

\begin{tabular}{lll}
\hline Property & Hydrogen & Gasoline \\
\hline Molecular mass $(\mathrm{kg} / \mathrm{kmol})$ & 114 & 2.016 \\
Theoretical air-fuel ratio $(\mathrm{kg} / \mathrm{kg}$ comb) & 14.5 & 34.32 \\
Density, at $0^{\circ} \mathrm{C}$ and $760 \mathrm{~mm} \mathrm{Hg},(\mathrm{kg} / \mathrm{m3}$ & $0.735-0.760$ & 0.0899 \\
Flammability limits in air, at $20^{\circ} \mathrm{C}$ and $760 \mathrm{~mm} \mathrm{Hg} \%$ vol. & $1.48-2.3$ & $4.1-75.6$ \\
$\lambda$ & $1.1-0.709$ & $10.12-0.136$ \\
Flame velocity in air $(\lambda=1)$, at $20^{\circ} \mathrm{C}$ and $760 \mathrm{~mm} \mathrm{Hg}(\mathrm{m} / \mathrm{s})$ & 0.12 & 2.37 \\
Octane number & $90-98$ & $>130$ \\
Min. ignition energy in air $(\mathrm{mJ})$ & $0.2-0.3$ & 0.018 \\
Auto-ignition temperature $(\mathrm{K})$ & $753-823$ & $848-853$ \\
Lower Heating Value $\left(\right.$ gas at $0^{\circ} \mathrm{C}$ and $\left.760 \mathrm{~mm} \mathrm{Hg}\right)$ & 3661 & 3178 \\
Stoichiometric fuel-air mixture $(\mathrm{kJ} / \mathrm{m3})(\mathrm{kJ} / \mathrm{kg})$ & 42690 & 119600 \\
\hline
\end{tabular}

All the data such as engine speed and $\mathrm{HC}$, and $\mathrm{CO}$ emissions were measured using a Dynamometer and Automotive Gas Analyzer, as shown in Figure 2. All the measured data are recorded in tabular form. This data was entered into the Expert Design application (DOE) software to conduct statistical analysis based on the two-level factorial full design approach (RBFAD) [26,27]. Analysis of variance, using ANOVA, was used to identify the relationship between the controlled parameters and the significant influence. In this study, one mm-thick of stainless steel was chosen as the electrode plate material due to its affordable cost, suitability, and in-market availability. Stainless steel offers superior mechanical qualities at room temperature compared to other materials. It combines ductility, elasticity, and hardness, allowing it to be employed in difficult metal forming modes (deep stamping, flat bending, extrusion, and so on) while also providing heavy wear resistance (friction, abrasion, impact, elasticity, etc.). It also has good mechanical properties at both high and low temperatures. Two sets of stainless steel were cut into two different sizes and labelled with a group A1 for an area of $10 \mathrm{~cm} \times 30 \mathrm{~cm} \times 2\left(600 \mathrm{~cm}^{2}\right)$ and group A2 for $20 \mathrm{~cm} \times 30 \mathrm{~cm} \times 2\left(1200 \mathrm{~cm}^{2}\right)$. The total number of stainless-steel plates for each group, $A 1$, and $A 2$, together with the area, is 24 pieces. The characteristic of electrode plates based on matrix experiments proposed by the RBFAD approach is given in Table 3. The 16 experiments were done by using the number of electrodes 12 and 24; the distance between electrode plates were 1 and $2 \mathrm{~cm}$, and the area of electrode plates were 600 and $1200 \mathrm{~cm}^{2}$.

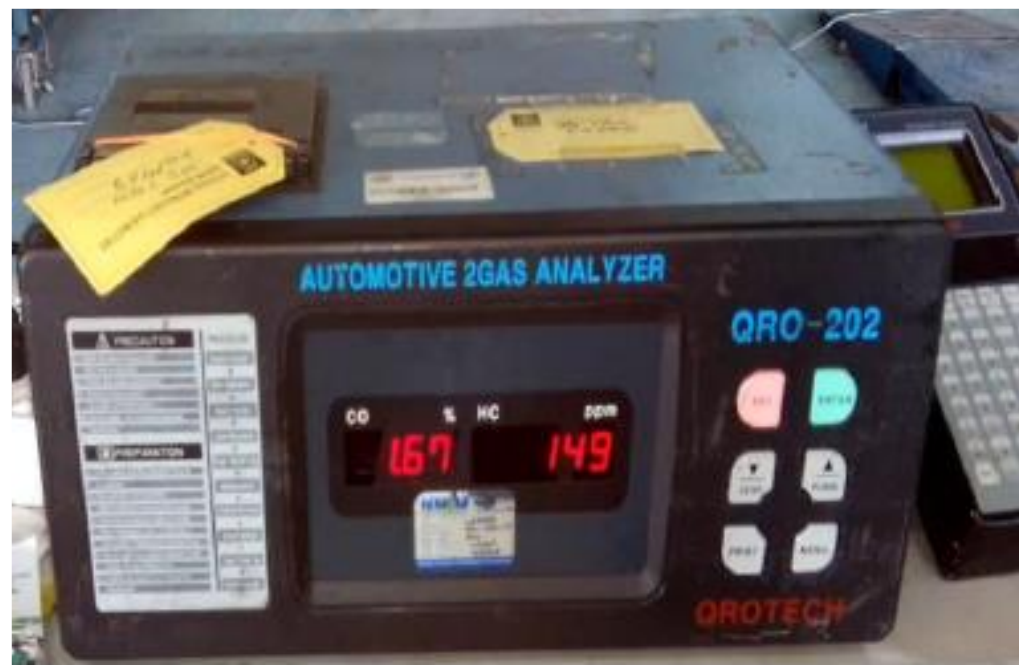

Fig. 2. HC and CO measurement instrument (Model: QRO-202) 
Table 3

The characteristic of electrode plates

\begin{tabular}{llll}
\hline No. & Number of electrodes & Distance between electrode plates $(\mathrm{cm})$ & Area of electrode plates $\left(\mathrm{cm}^{2}\right)$ \\
\hline 1 & 24 & 1 & 1200 \\
2 & 24 & 2 & 1200 \\
3 & 24 & 1 & 600 \\
4 & 12 & 1 & 600 \\
5 & 12 & 2 & 600 \\
6 & 12 & 1 & 1200 \\
7 & 24 & 2 & 600 \\
8 & 12 & 2 & 1200 \\
9 & 24 & 1 & 1200 \\
10 & 24 & 2 & 1200 \\
11 & 24 & 1 & 600 \\
12 & 12 & 1 & 600 \\
13 & 12 & 2 & 600 \\
14 & 12 & 1 & 1200 \\
15 & 24 & 2 & 600 \\
16 & 12 & 2 & 1200 \\
\hline
\end{tabular}

\subsection{HHO Gas Generator and Fuel Cell Fabrication}

To trigger the process of water electrolysis, an electric current has to be flowed through the electrolyte using an electrode plate connected to the positive terminal called the anode and an electrode plate attached to the negative terminal called the cathode. A fixed rated direct current electricity of 10-Amp 18-Volt is supplied to the electrode plate [28]. Two sets of power suppliers were developed to supply 10-amp, 18-volt direct current electricity to the $\mathrm{HHO}$ gas generator to trigger the electrolysis operation. The step-down transformer (SDT) is used since the source of electrical power supplied by TNB is 240 volts. A total of 6 SDT were connected to 12 electrode plates, and 12 SDT were connected to 24 plate electrodes. Figure 3 shows a schematic diagram of 24 plates representing 12 sets of electrode plates (1 plate each for the anode and cathode), including a distance between $1 \mathrm{~cm}$ and an area of $1200 \mathrm{~cm}^{2}$ for the electrolysis process.

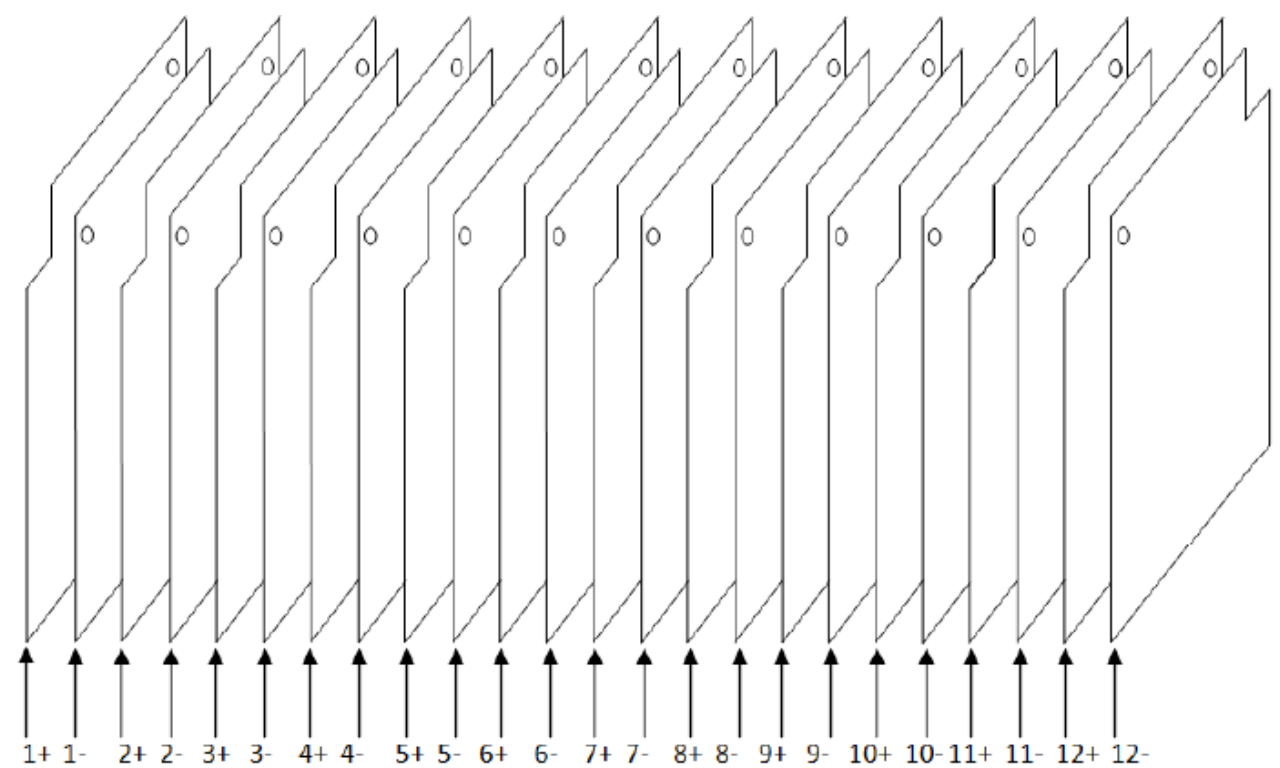

Fig. 3. 24 electrode plates 


\subsection{Statistical Analysis}

Statistical analysis of engine speed and exhaust gas emissions was analyzed using variance or ANOVA analysis, taking into account the alpha $(\alpha)$ level was 0.05 with a corresponding confidence level of $95 \%$. The $\mathrm{F}$ test in the ANOVA table is to determine whether there is a significant influence and interaction between the controlled factors in this study. Therefore, the use of ANOVA in this study evaluates the main influence and interaction between controlled factors in the electrode design that significantly affect engine performance, $\mathrm{CO}$ and $\mathrm{HC}$ gas emissions.

\section{Results and Discussion}

\subsection{Results}

Experiments were performed based on Table 3. Each investigation was conducted for 7 minutes, equivalent to 1 litre of gasoline. This step lasted until 16 experimental tests were done. All data collected will be used in RBFAD and ANOVA analysis through the Design Expert application. The average benchmark data values related to the engine rotation speed (1754 rpm), HC concentration (150) and CO percentage (3.13) measured and recorded are in Table 4.

\section{Table 4}

Benchmark data

\begin{tabular}{llllll}
\hline Test & RPM & $\mathrm{HC} \mathrm{ppm}$ & CO Percentage & 1 litre of Petrol & Heat \\
\hline 1 & 1754 & 150 & 3.13 & $7 \mathrm{~min}$ & $30.0^{\circ} \mathrm{C}$ \\
2 & 1754 & 148 & 3.14 & $7 \mathrm{~min}$ & $30.1^{\circ} \mathrm{C}$ \\
3 & 1754 & 151 & 3.12 & $7 \mathrm{~min}$ & $30.1^{\circ} \mathrm{C}$ \\
4 & 1754 & 149 & 3.13 & $7 \mathrm{~min}$ & $30.0^{\circ} \mathrm{C}$ \\
5 & 1754 & 150 & 3.13 & $7 \mathrm{~min}$ & $30.2^{\circ} \mathrm{C}$ \\
Average & 1754 & 150 & 3.13 & $7 \mathrm{~min}$ & $30.2^{\circ} \mathrm{C}$ \\
\hline
\end{tabular}

RBFAD -based Design Expert application version 9, which refers to a $2 \mathrm{k}$ factorial design where $\mathrm{k}$ is the number of parameters studied. This formulation was used to determine the number of experiments to be conducted based on three controlled factors which are number, distance and area as shown in Table 5. A total of 8 experiments with 1 repetition were proposed for this study by RBFAD. The results of the experimental tests are shown in Table 6. The average values of these data which are $2203 \mathrm{rpm}, 1.78 \%$ and 64 PPM for engine rotation, $\mathrm{CO}$ and $\mathrm{HC}$, respectively will be used as a benchmark and optimization of experimental test comparisons for engine speed and gas emissions.

Table 5

Parameters of electrode plates for $\mathrm{HHO}$ gas generator

\begin{tabular}{llll}
\hline Controlled parameters (Electrode plates) & Unit & Min & Max \\
\hline A-Number & Plates & 12 & 24 \\
B-Distance & $\mathrm{cm}$ & 1 & 2 \\
C-Area & $\mathrm{cm}^{2}$ & 600 & 1200 \\
\hline
\end{tabular}


Table 6

Experimental results

\begin{tabular}{|c|c|c|c|c|c|c|}
\hline \multirow[b]{2}{*}{ No. } & \multicolumn{3}{|c|}{ Controlled factors (Electrode plates) } & \multicolumn{3}{|l|}{ Experimental results } \\
\hline & Number & Distance $(\mathrm{cm})$ & Area $\left(\mathrm{cm}^{2}\right)$ & Engine rotation (rpm) & $\mathrm{CO}(\%)$ & $\mathrm{HC}(\mathrm{ppm})$ \\
\hline 1 & 24 & 1 & 1200 & 2346 & 1.82 & 52 \\
\hline 2 & 24 & 2 & 1200 & 2270 & 1.78 & 47 \\
\hline 3 & 24 & 1 & 600 & 2215 & 1.74 & 46 \\
\hline 4 & 12 & 1 & 600 & 2182 & 1.71 & 45 \\
\hline 5 & 12 & 2 & 600 & 2174 & 1.76 & 53 \\
\hline 6 & 12 & 1 & 1200 & 2163 & 1.86 & 69 \\
\hline 7 & 24 & 2 & 600 & 2141 & 1.81 & 95 \\
\hline 8 & 12 & 2 & 1200 & 2135 & 1.79 & 107 \\
\hline 9 & 24 & 1 & 1200 & 2342 & 1.82 & 51 \\
\hline 10 & 24 & 2 & 1200 & 2267 & 1.76 & 47 \\
\hline 11 & 24 & 1 & 600 & 2217 & 1.73 & 43 \\
\hline 12 & 12 & 1 & 600 & 2183 & 1.69 & 46 \\
\hline 13 & 12 & 2 & 600 & 2173 & 1.77 & 51 \\
\hline 14 & 12 & 1 & 1200 & 2160 & 1.84 & 68 \\
\hline 15 & 24 & 2 & 600 & 2138 & 1.8 & 92 \\
\hline 16 & 12 & 2 & 1200 & 2134 & 1.79 & 109 \\
\hline \multicolumn{4}{|c|}{ Average } & 2203 & 1.78 & 64 \\
\hline
\end{tabular}

\subsection{Effect of Electrode Plates on the Engine Performance}

The ANOVA table for engine performance is shown in Table 7. From the observations made on the statistical values, $R^{2}$ is $0.9997, A_{d j} R^{2}$ is 0.9994 , which indicates a reasonable agreement. The Adeq precision $(\mathrm{AP})=167.600$ greater than 4 is desirable, as it measures the signal-to-noise ratio. $\mathrm{A}$ similar result is generated for $P$ when the value is smaller than 0.05 . This means that the primary influence and interaction between controlled factors significantly impact engine speed efficiency.

The mathematical model as a function of describing the rotational speed of the engine consists of the distance, number, and area are as follows: -

Engine speed $=470.68877-(2.51350 *$ Number of electrode plates $)+(95.83071 *$ Distance (rev/min) between electrode plates $-(0.23636 *$ Area of electrode plates $)-(7.22249 *$ Number of electrode plates * Distance between electrode plates $)+(0.019252$ * Number of electrode plates * Area of electrode plates) $-(0.065753 *$ Distance between electrode plates * Area of electrode plates $)+(2.81376 \mathrm{E}-003 *$ Number of electrode plates * Distance between electrode plates * Area of electrode plates) 
Table 7

Analysis of variance (ANOVA) for engine performance

\begin{tabular}{llllll}
\hline Source & $\begin{array}{l}\text { Sum of } \\
\text { Squares }\end{array}$ & Df & Mean Square & F Value & $\begin{array}{l}\text { p-value } \\
\text { Prob }>\text { F }\end{array}$ \\
\hline Model & 72151 & 7 & 10307 & 3298.33 & $<0.0001$ \\
A (number of electrode plates & 24947 & 1 & 24947 & 7982.99 & $<0.0001$ \\
B (distance between electrode & 8835 & 1 & 8835 & 2827.34 & $<0.0001$ \\
plates & & & & & \\
C (area of electrode plates & 9702 & 1 & 9702 & 3104.72 & $<0.0001$ \\
AB & 3364 & 1 & 3364 & 1076.60 & $<0.0001$ \\
AC & 25122 & 1 & 25122 & 8039.12 & $<0.0001$ \\
BC & 72 & 1 & 72 & 23.12 & 0.0013 \\
ABC & 90 & 1 & 90 & 28.88 & 0.0007 \\
Pure Error & 25 & 8 & 3 & & \\
Cor Total & 72176 & 15 & & & \\
\hline
\end{tabular}

The effect of these controlled elements is determined by comparing the values of the benchmark data in Table 4 with the experimental results in Table 6, as shown in this table. There is an increase in the engine rotational speed and a reduction in $\mathrm{HC}$ and $\mathrm{CO}$ gas emissions. These findings are also supported by El-Kassaby et al., [29], Madyira and Harding [30], Yilmaz et al., [31]. Therefore, it is concluded that the number of electrode plates (A), the distance between the electrode plates (B), and the area of the electrode plates (C) have a significant influence and interaction. The effect of electrode plates parameters on the engine speed performance can be compared with the help of perturbation plots, as illustrated in Figure 4. The perturbation plot facilitates observing all influencing factors at the center point in the design space for coded values. The line gradients in the graph show the influence and sensitivity of the respective electrode plate parameters for engine speed performance. As shown in Figure 4, the trends for the number of electrode plates $(A)$ and the area of the electrode plates $(C)$ have the same gradient. By increasing the number and area of the electrode plates can cause the engine speed to increase.

The area surface of the electrode plate plays an important role in the hydrogen production system through electrolysis. The larger area of the electrode plates will cause more water molecules to decompose and form hydrogen gas and oxygen gas [32]. However, the engine speed performance decreased as the distance between the electrode plates (B) increased. This finding is consistent with De Silva et al., [33], who found that the current used by the HHO generator is inversely proportional to the distance between the electrode plates. The result can be explained by the fact that when the distance between the electrodes is too far, the influence of the electric current becomes weak the process of electrolysis of water cannot be done well. This condition simultaneously reduces the formation of $\mathrm{H}_{2}$ and $\mathrm{O}_{2}$, because according to Faraday's law of electrolysis, the rate of hydrogen production is directly proportional to the current $[34,35]$. 


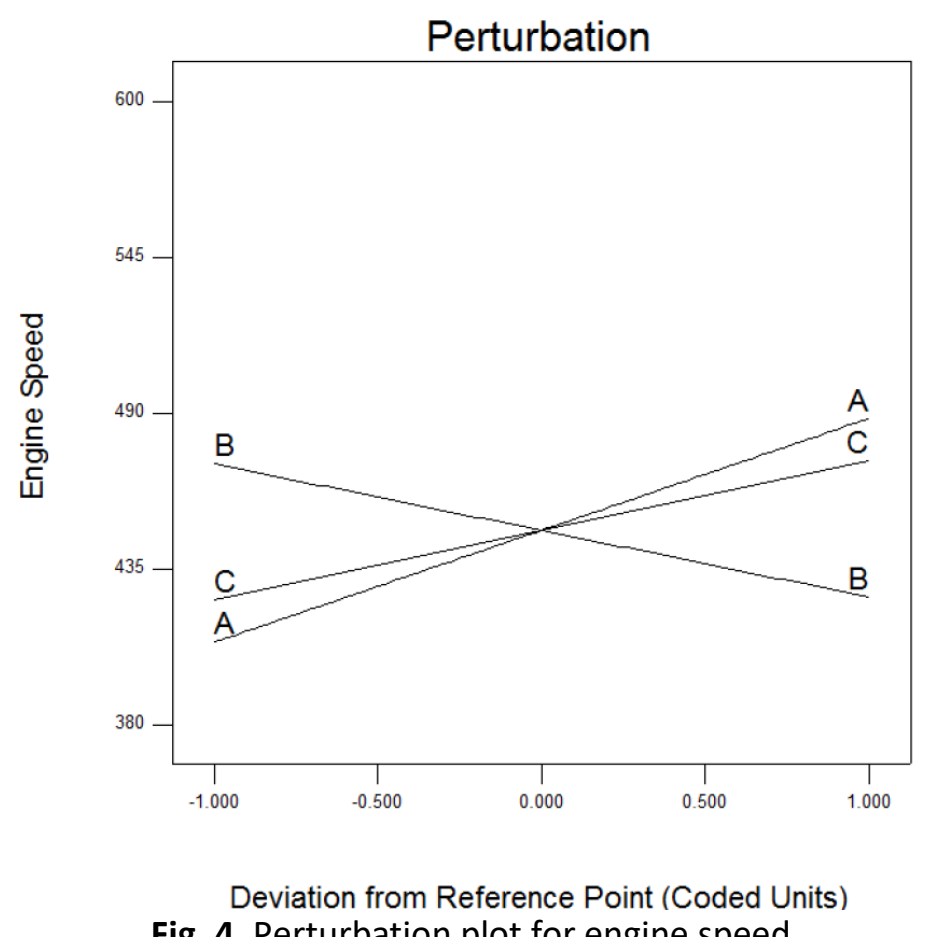

Fig. 4. Perturbation plot for engine speed

The interaction of the controlled factors with the engine speed is plotted in Figure 5. As in Figure $5(a)$, using a distance of $1 \mathrm{~cm}$ on 24 electrode plates decreases the water resistance, causing more electric current to flow [36,37]. In general, electric current plays an essential role in the production of hydrogen and oxygen. Thus, many electrode plates produce many gas bubbles, which interact with a high electric current that can break down the molecular mass of water into oxygen gas and hydrogen gas. However, by using a distance of $1 \mathrm{~cm}$ on 12 electrode plates, the speed of the machine decreased. These results may reflect insufficient HHO gas production because the number of electrode plates is the dominant factor of the electrode plate distance, as found by the ANOVA results in Table 7. It was found that the interaction of the number of electrode plates, and distance of electrode plates $(A B)$, number of electrode plates and area of electrode plates (AC), a distance of electrode plates and area of electrode plates (BC) had a significant effect on engine speed, as presented in Table 7 referred to the values $-p$.

The relation between the area and the number of electrode plates, as determined by the ANOVA in Table 7, significantly impacts the engine rpm. As several electrode plates interact with a large area of the electrode plates, as seen in Figure 5(b), an improvement in the engine speed can be achieved. Although the number of electrode plates was a significant factor in producing $\mathrm{HHO}$ gas, the results found that the number of plates had little effect on engine speed when interacting with a smaller electrode plate area. This phenomenon occurs due to Ohmic resistance as described when bubbles form and rise to the plate surface. The newly formed bubbles will accumulate into the newly formed bubbles and can cover some of the areas of the electrode plate. And at the same time, it prevents water from touching the plate surface to reduce the flow of electric current, causing the system formation rate to decrease oxygen and hydrogen production [38].

An adequate distance between the electrode and a wide water contact area on the electrode plate's surface leads to an improvement in oxygen and hydrogen gases, instantly improving the engine's speed efficiency. This setup allows for a smooth flow of electricity through each electrode plate. This phenomenon is also stated by Jumiati et al., [39]. They emphasize that the design and dimensions of the fuel cell, such as the area of the electrode plates, can regulate internal combustion efficiency. The greater the area of the electrode plates traversed by water, the more water molecules 
are affected, forming hydrogen and oxygen atoms. When $\mathrm{H}_{2}$ is combined with $\mathrm{O}_{2}$, its explosive nature causes an increase in engine speed.

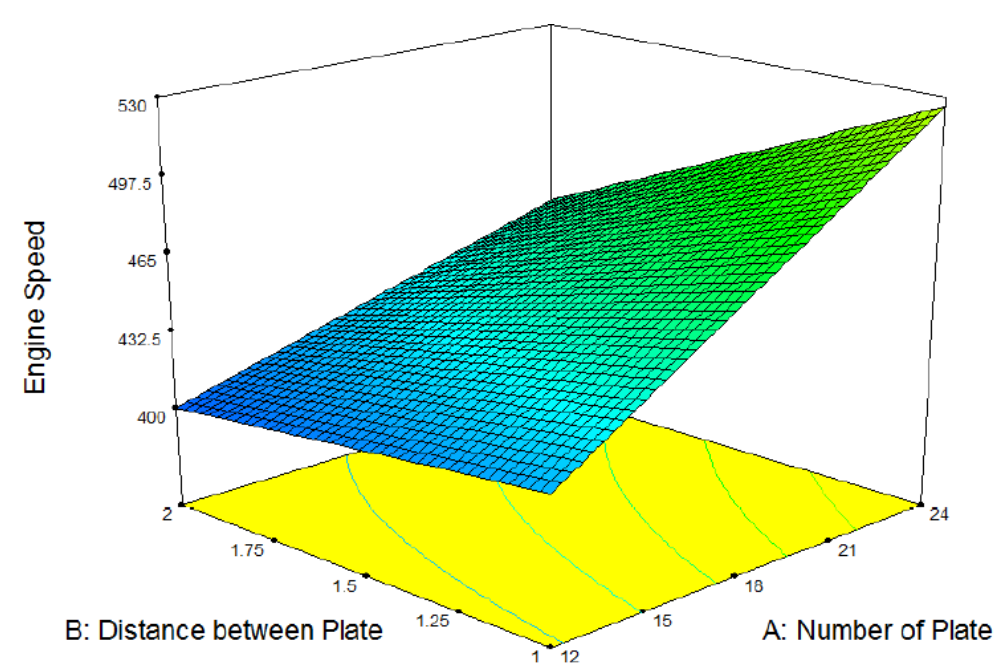

(a) Interaction of distance between plates and number of plates

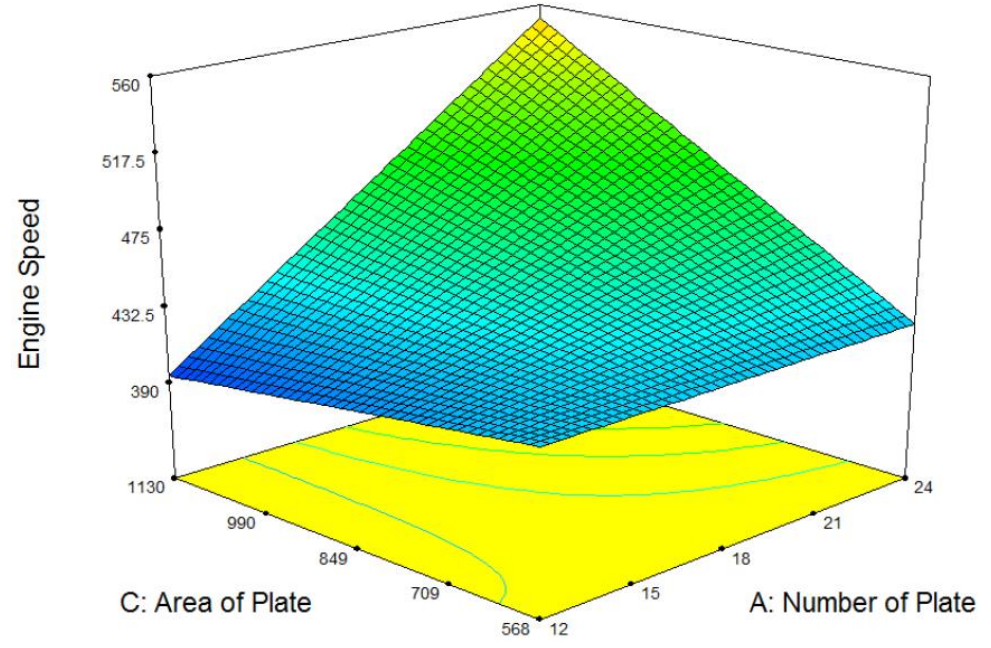

(b) Interaction of area of plates and number of plates

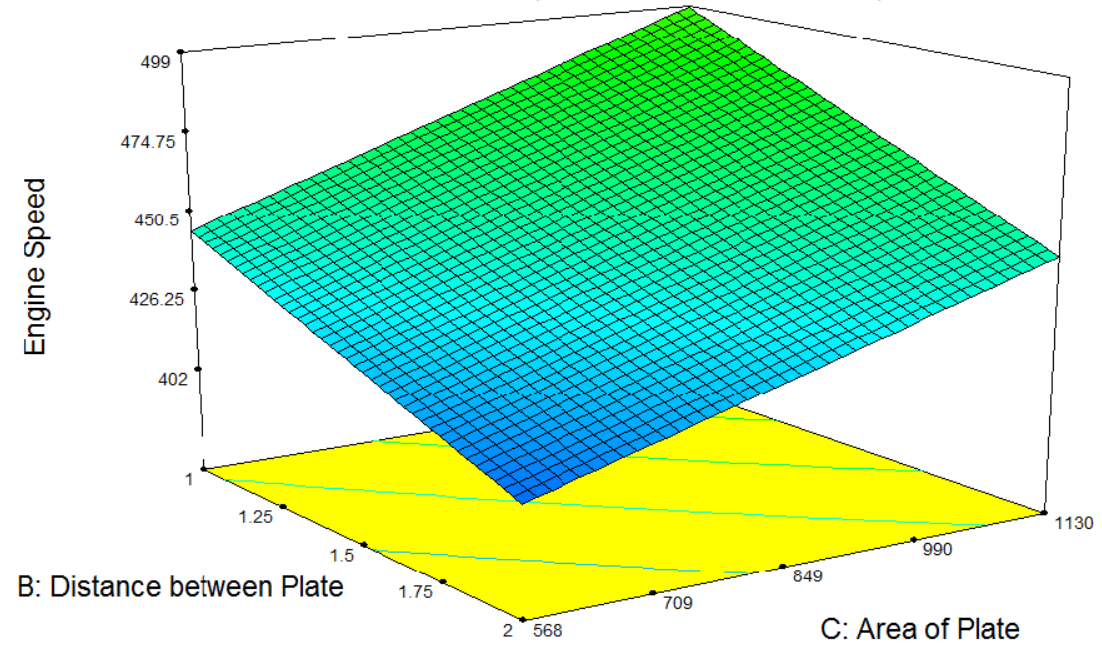

(c) Interaction of distance between plates and area of plates

Fig. 5. The interactions of controlled factors (electrode plates) to the engine speed 


\subsection{Effect of Electrode Plates on the Reduction of CO Gas Emissions}

The ANOVA table for CO gas emissions is shown in Table 8. The result of $R^{2}$ is $0.9970, A d j R^{2}$ is 0.9986, which indicates a reasonable agreement with each other. The AP is 97.599. As mentioned earlier, AP greater than 4 is acceptable. The mathematical model as a function of describing the reducing $\mathrm{CO}$ gas emissions consists of the distance, number, and area are as follows: -

$\mathrm{CO}=(0.28689 *$ Number of electrode plates $)+(4.95593 *$ Distance between electrode plates $)$ $+(7.02847 \mathrm{E}-003 *$ Area of electrode plates) $-(0.30359 *$ Number of electrode plates * Distance between electrode plates) - (3.75415E-004* Number of electrode plates * Area of electrode plates) - (7.14398E-003* Distance between electrode plates * Area of electrode plates $)+(3.82079 \mathrm{E}-004 *$ Number of electrode plates * Distance between electrode plates * Area of electrode plates) -2.78535

The effect of electrode plate parameters on reducing $\mathrm{CO}$ gas emissions in the exhaust gas can be compared with the help of perturbation plots, as illustrated in Figure 6. According to Figure 6, the number of electrode plates (A) and the area of the electrode plates (C) have the same gradient. Increasing the number of electrode plates and the area of the electrode plates can lead to a reduction in $\mathrm{CO}$ gas production [40]. The interaction of the controlled factors with the $\mathrm{CO}$ gas emission in the exhaust gas is plotted in Figure 7. It was found that the interaction of $A B, A C$ and $B C$ had a significant effect on the CO gas emissions, as shown in Table 8.

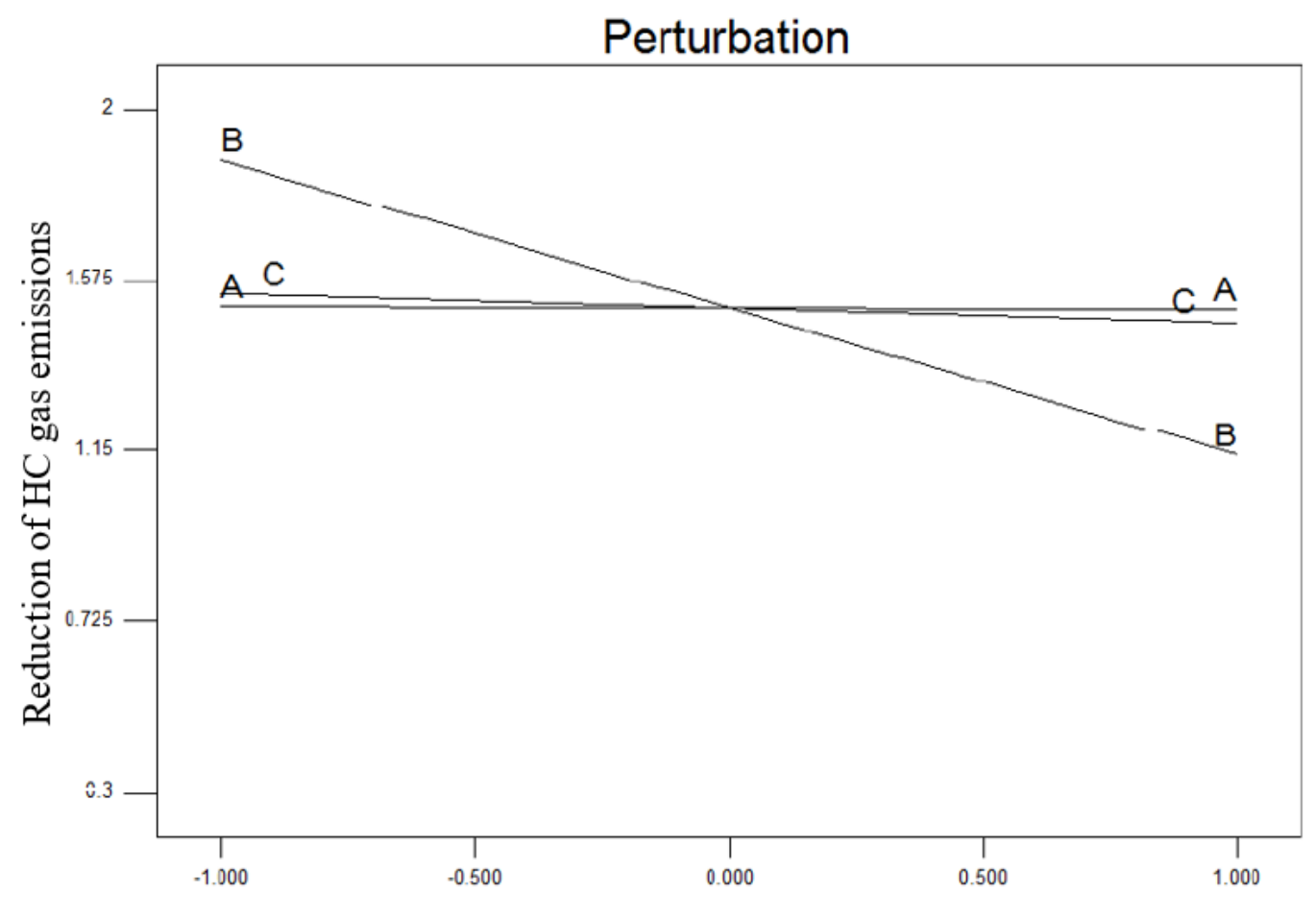

Deviation from Reference Point (Coded Units)

Fig. 6. Perturbation plot for $\mathrm{CO}$ gas emissions in the exhaust gas 


\section{Table 8}

Analysis of variance (ANOVA) for CO gas emissions

\begin{tabular}{|c|c|c|c|c|c|}
\hline Source & $\begin{array}{l}\text { Sum of } \\
\text { Squares }\end{array}$ & Df & Mean Square & F Value & $\begin{array}{l}\text { p-value } \\
\text { Prob> F }\end{array}$ \\
\hline Model & 5.71 & 7 & 0.82 & 1518.53 & significant \\
\hline A (number of electrode plates & $2.250 \mathrm{E}-004$ & 1 & $2.250 \mathrm{E}-004$ & 0.42 & $<0.5358$ \\
\hline B (distance of electrode plates & 2.16 & 1 & 2.16 & 4020.28 & $<0.0001$ \\
\hline C (area of electrode plates & 0.021 & 1 & 0.021 & 39.12 & $<0.0002$ \\
\hline$A B$ & 0.063 & 1 & 0.063 & 116.28 & $<0.0001$ \\
\hline$A C$ & 1.78 & 1 & 1.78 & 3315.77 & $<0.0001$ \\
\hline$B C$ & 0.022 & 1 & 0.022 & 41.86 & 0.002 \\
\hline$A B C$ & 1.66 & 1 & 1.66 & 3096 & $<0.0001$ \\
\hline Pure Error & 4.300E-003 & 8 & 5.375E-004 & & \\
\hline Cor Total & 5.72 & 15 & & & \\
\hline
\end{tabular}

Using a minimum distance configuration on 24 electrode plates, the results indicate that CO reduction has occurred [40]. However, using the minimum distance on 12 electrode plates, the CO reduction was not significant compared to higher electrode plate spacing. These results may reflect insufficient $\mathrm{HHO}$ gas production because the number of plates is the dominant factor of the plate distance. The relation between the area and the number of electrode plates, as determined by the ANOVA in Table 8, has a significant impact on the $\mathrm{CO}$ gas emissions. According to Figure 7(b), $\mathrm{CO}$ reduction can be achieved when a high number of plates interact with the area of electrode plates. Although the surface area of the electrode plate is a significant factor in producing $\mathrm{HHO}$ gas, the results found that the number of plates had little effect on $\mathrm{CO}$ gas emissions when interacting with the smaller area of the electrode plates. As mentioned previously, this phenomenon occurs due to Ohmic resistance [39]. According to Figure 7(c), a sufficient distance between the electrode plates and the area of electrode plates leads to an increase in $\mathrm{H}_{2}$ and $\mathrm{O}_{2}$ gas production, thus lowering $\mathrm{CO}$ emissions. This electrode plate has a large surface area that allows electric current to flow freely. This result has an agreement with the studies by Uludamar et al., [40], and Calo [41]. CO gas is produced when fuel is burned without enough oxygen to contain carbon dioxide (CO2).

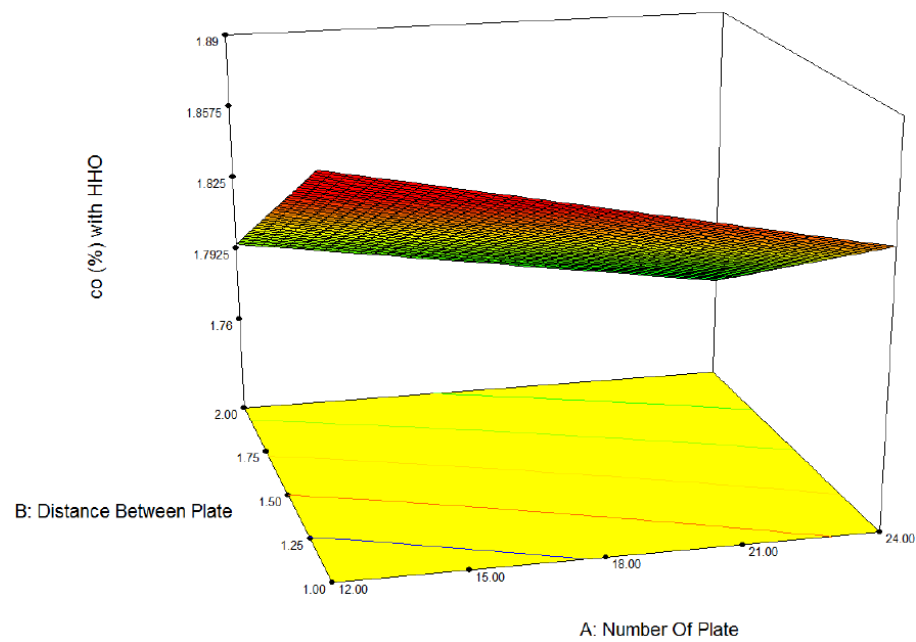

(a) Interaction of distance between plates and area of plates 


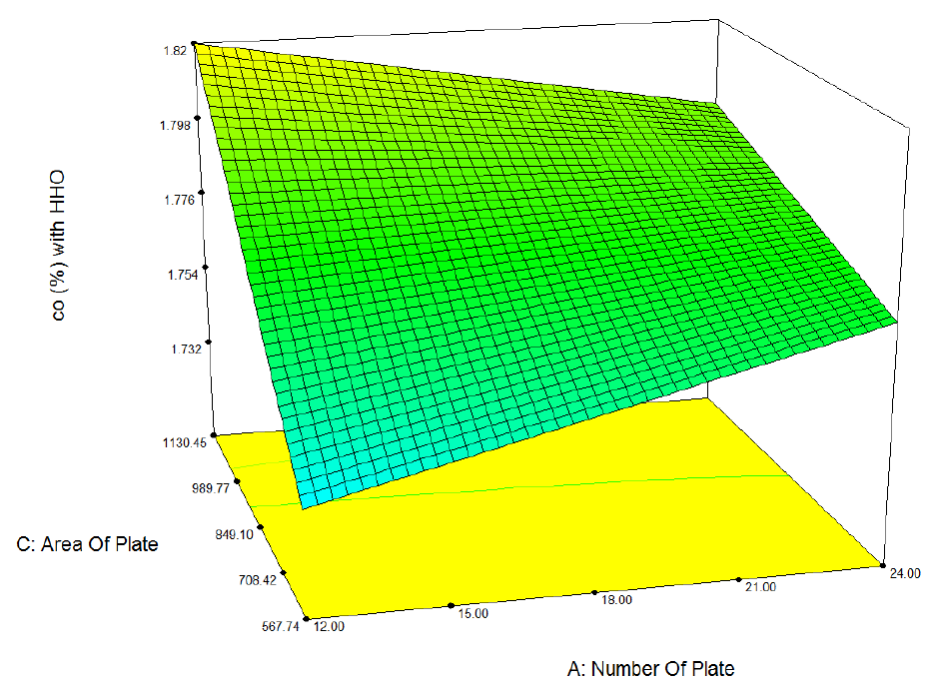

(b) Interaction of area of plates and number of electrode plates

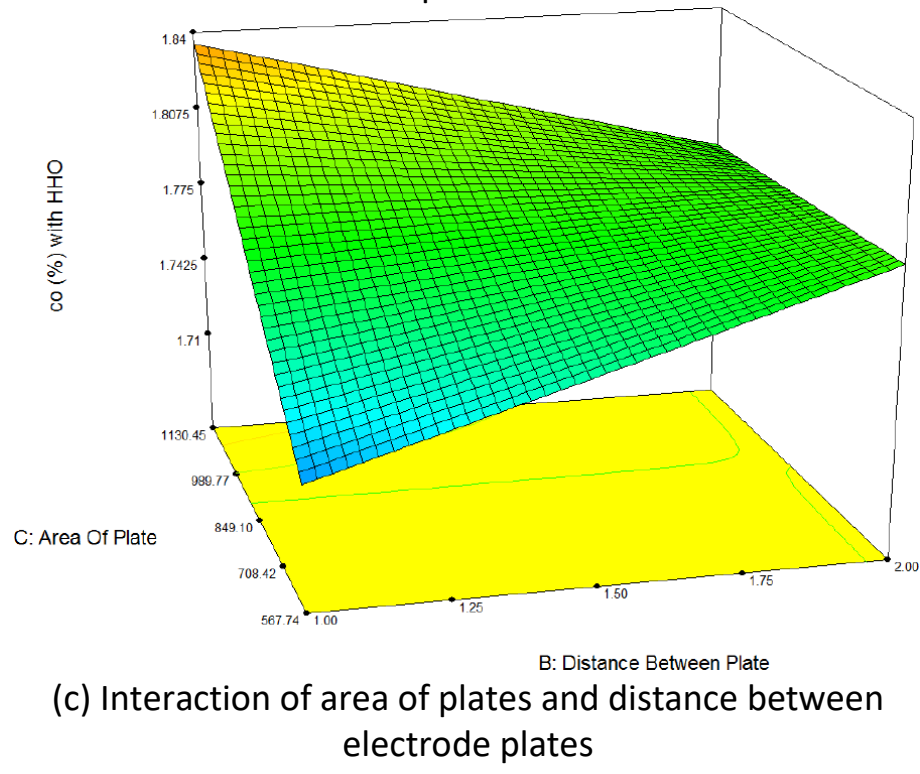

Fig. 7. The interactions of controlled factors (electrode plates) to the $\mathrm{CO}$ gas emissions

\subsection{Effect of Electrode Plates on the Reduction of HC Gas Emissions}

The ANOVA table for HC gas emissions is shown in Table 9. The result of $R^{2}$ is $0.9915, A d j R^{2}$ is 0.9840, which indicates a reasonable agreement with each other. The AP is 42.286. As mentioned earlier, AP greater than 4 is acceptable. The mathematical model as a function of describing the reducing $\mathrm{HC}$ gas emissions consists of the distance, number, and area are as follows: -

$\mathrm{HC}=(8.36503 *$ Number of electrode plates $)+(130.15749 *$ Distance between electrode plates $)+(0.35809 *$ Area of electrode plates $)-(5.38100 *$ Number of electrode plates * Distance between electrode plates $))-(0.014587 *$ Number of electrode plates * Area of electrode plates) $-\left(0.23014 *\right.$ Distance between electrode plates) ${ }^{*}$ Area of electrode plates $)+(9.47792 \mathrm{E}-003 *$ Number of electrode plates * Distance between electrode plates) * Area of electrode plates) - 161.30104 
Table 9

Analysis of variance (ANOVA) for HC gas emissions

\begin{tabular}{|c|c|c|c|c|c|c|}
\hline Source & $\begin{array}{l}\text { Sum of } \\
\text { Squares }\end{array}$ & Df & $\begin{array}{l}\text { Mean } \\
\text { Square }\end{array}$ & F Value & $\begin{array}{l}\text { p-value } \\
\text { Prob }>F\end{array}$ & \\
\hline Model & 4416 & 7 & 630.86 & 132.81 & $<0.0001$ & significant \\
\hline A (number of electrode plates & 0.25 & 1 & 0.25 & 0.053 & 0.8243 & \\
\hline B (distance of electrode plates & 1190.25 & 1 & 1190.25 & 250.58 & $<0.0001$ & \\
\hline C (area of electrode plates & 49 & 1 & 49 & 10.32 & 0.0124 & \\
\hline$A B$ & 1024 & 1 & 1024 & 215.58 & $<0.0001$ & \\
\hline$A C$ & 6.25 & 1 & 6.25 & 1.32 & 0.2845 & \\
\hline $\mathrm{BC}$ & 1122.25 & 1 & 1122.25 & 236.26 & $<0.0001$ & \\
\hline$A B C$ & 1024 & 1 & 1024 & 215.58 & $<0.0001$ & \\
\hline Pure Error & 38 & 8 & 4.75 & & & \\
\hline Cor Total & 4454 & 15 & & & & \\
\hline
\end{tabular}

The effect of electrode plate parameters on reducing $\mathrm{HC}$ gas emissions can be compared with the presence of perturbation plots, as illustrated in Figure 8. As shown in Figure 8, the trend is similar to the results of $\mathrm{CO}$ gas emissions. Increasing the number of electrode plates and the area of the electrode plates can lead to a reduction in $\mathrm{HC}$ gas production. $\mathrm{O}_{2}$ gas has benefited in completing the combustion, resulting in a decrease in the emissions of $\mathrm{HC}$ gas.

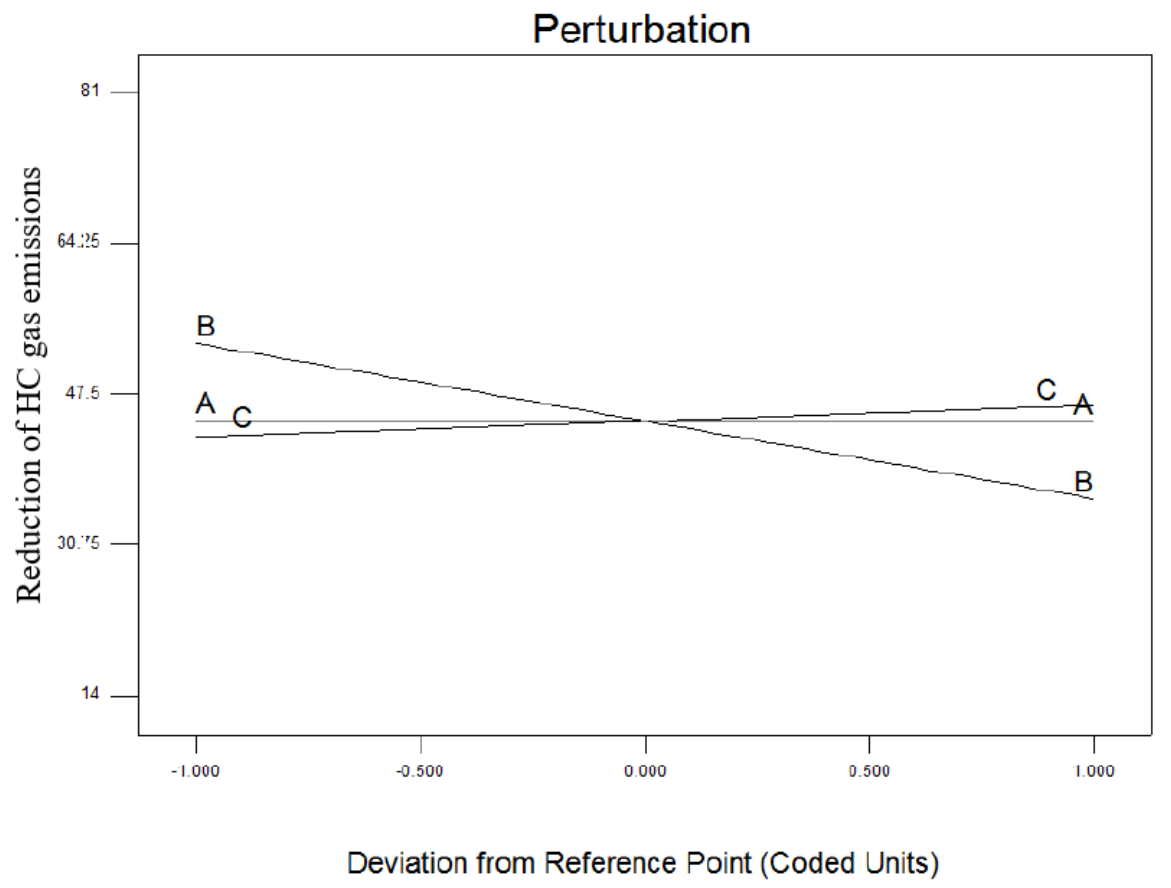

Fig. 8. Perturbation plot for HC gas emissions in the exhaust gas

The interaction of the controlled factors with the $\mathrm{CO}$ gas emission in the exhaust gas is plotted in Figure 9. It was found that the interaction of $A B, A C$ and $B C$ had a significant effect on the $C O$ gas emissions, as shown in Table 9. In general, electric current plays an important role in the production of $\mathrm{H} 2$ and $\mathrm{O} 2$ gases. In Figure 9(a), using the minimum distance and the maximum number of electrode plates, the water resistance decreases, causing the electric current flow to be higher $[36,41]$. HC, on the other hand, is closer to higher plate distances. These results can illustrate the unnecessary $\mathrm{H} 2$ and $\mathrm{O} 2$ gases production because the number of electrode plates is the dominant factor. However, the distance between electrode plates reduces $\mathrm{HC}$ almost to higher distance plates. 
These results may reflect insufficient $\mathrm{H}_{2}$ and $\mathrm{O}_{2}$ gas production because the number of plates is the dominant factor of plate distance.

The water resistance decreases in Figure 9(b) when the minimum distance and the maximum number of electrode plates are used, resulting in a higher electric current flow [34,36,41]. Electric current is crucial in the processing of $\mathrm{H}_{2}$ and $\mathrm{O}_{2}$ gases in general. Reduced $\mathrm{HC}$ almost results in a higher plate spacing using a minimum spacing and a minimum number of electrode plates. Since the number of plates is the most critical factor in plate distance, these findings could indicate a lack of $\mathrm{H}_{2}$ and $\mathrm{O}_{2}$ gas output. Among the interaction factors and terms, the interaction of area and the number of electrode plates greatly influence the HC production. Based on Figure 9(b), HC reduction can be achieved when the highest number of electrode plates interacts with a larger area of the electrode plates. Although the number of plates played a significant factor in producing $\mathrm{H}_{2}$ and $\mathrm{O}_{2}$ gases, the results found that the number of plates had little effect on the HC gas produced when interacting with a smaller area of electrode plates.

According to Figure 9(c), the minimum distance and maximum area of the electrode plates increase $\mathrm{H}_{2}$, and $\mathrm{O}_{2}$ gases immediately reduce the $\mathrm{HC}$. High $\mathrm{HC}$ gas emissions are due to imperfect gasoline combustion. $\mathrm{O}_{2}$ gas has benefited in completing the combustion, resulting in a decrease in the emissions of $\mathrm{HC}$ gas.

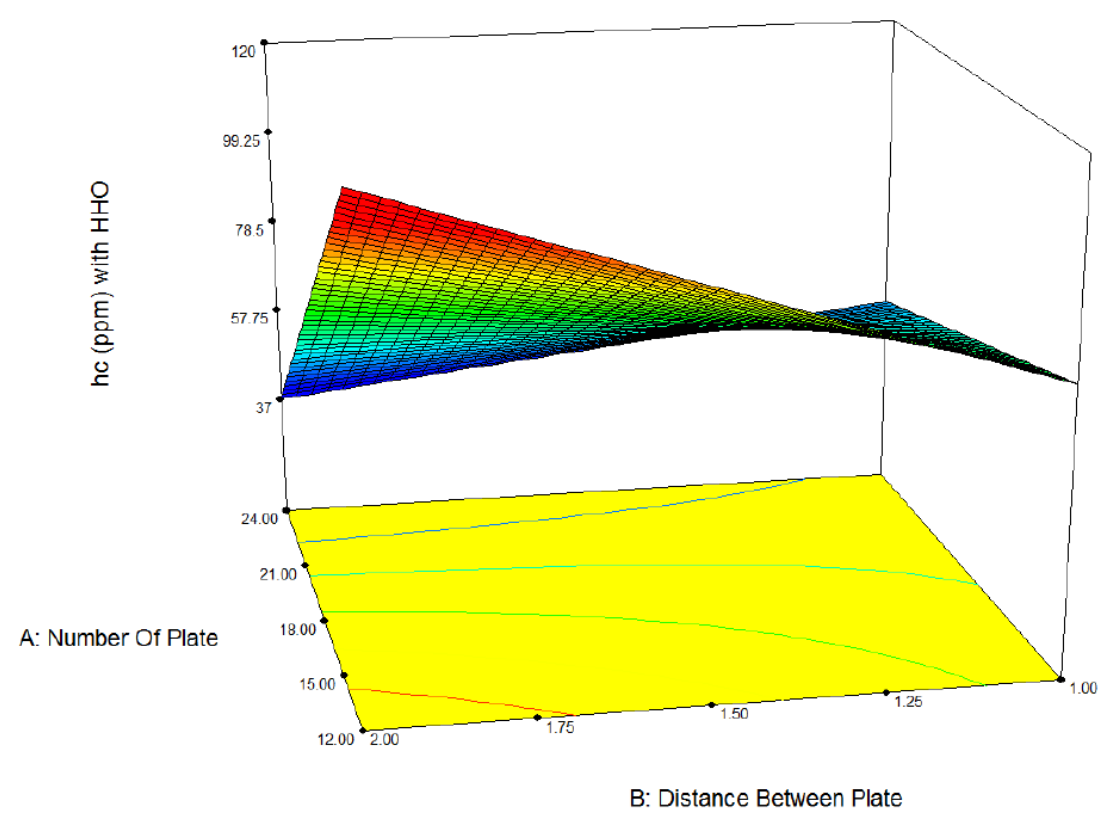

(a) Interaction of number of plates and distance between plates 


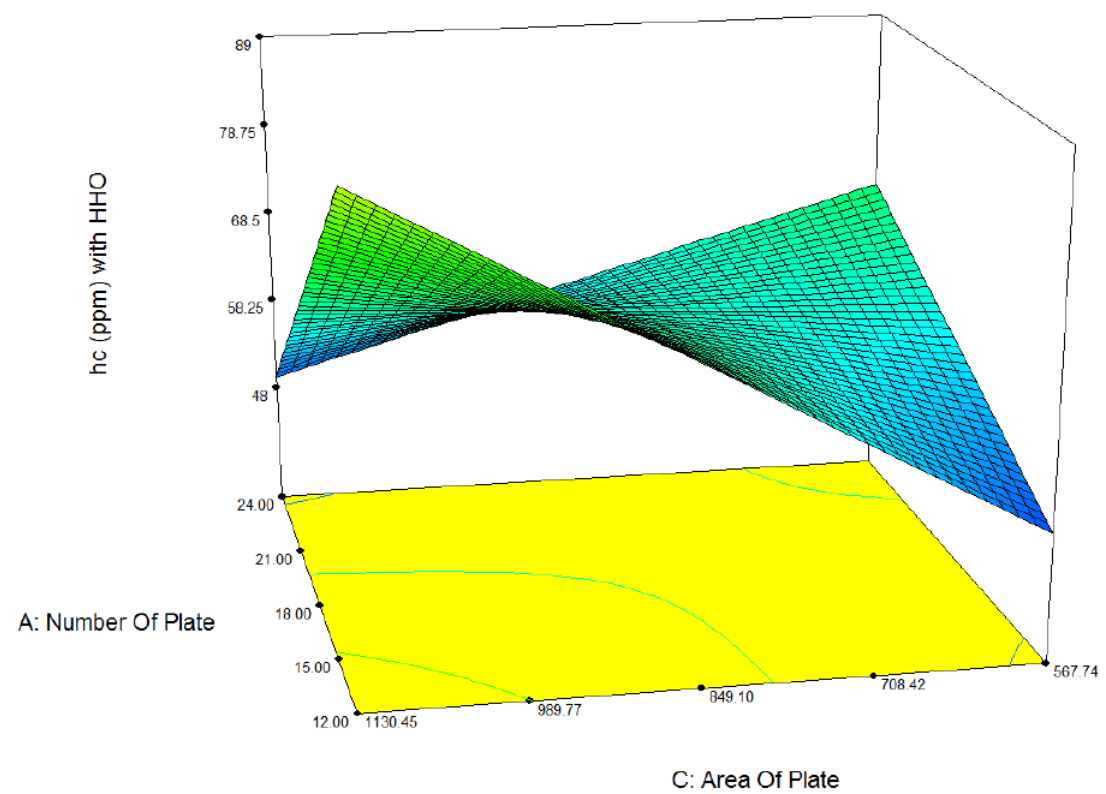

(b) Interaction of number of plates and area of electrode plates

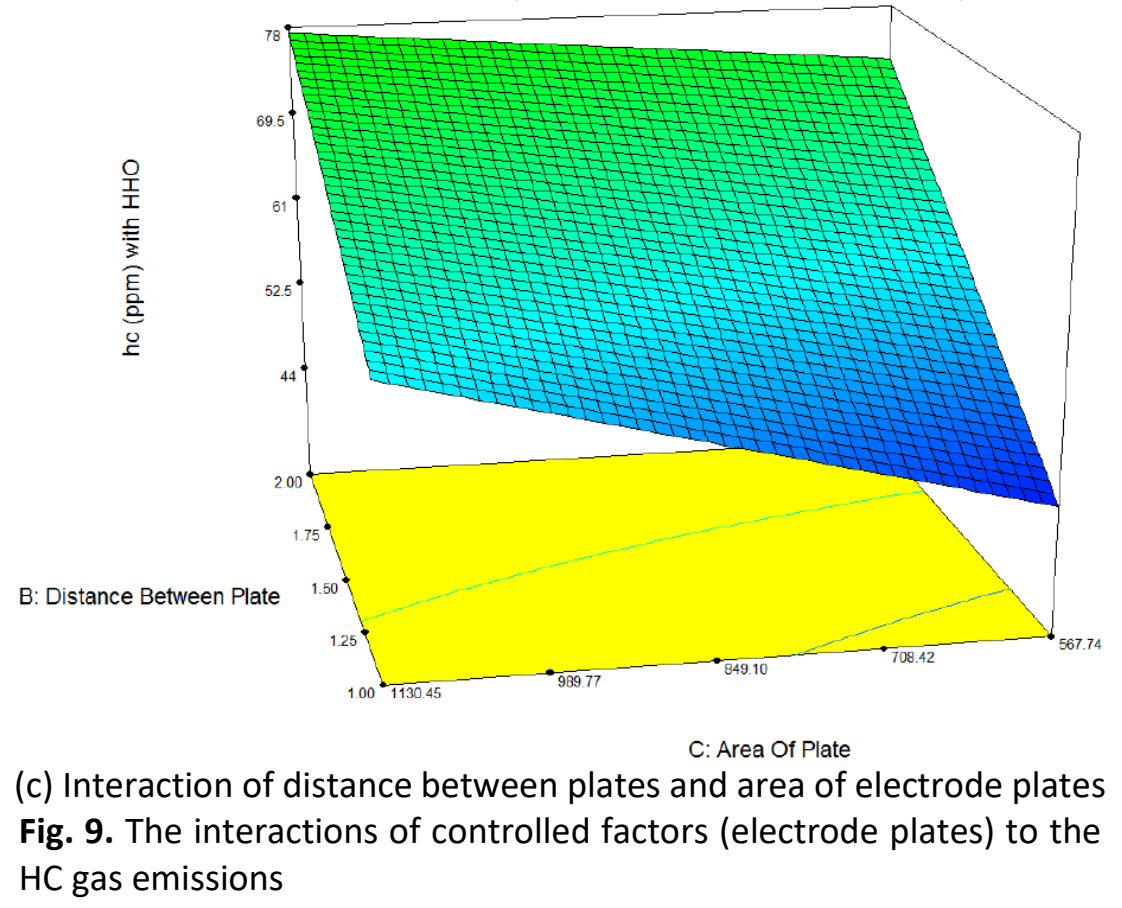

\section{Conclusion}

Hydrogen and oxygen gas ( $\mathrm{HHO}$ ) seemed to be the best possible alternative energy solution and were produced via water electrolysis. The effectiveness generation of HHO gas depends on the characteristic of the electrode plates. The following conclusions were obtained:

(i) It was found that the number of plates that interacted with a large area of electrode plate is a significant factor that caused an increase in engine speed on an average of $26 \%$, an average reduction in $\mathrm{CO}$ by $43 \%$, and a decrease in $\mathrm{HC}$ gas by $42 \%$.

(ii) The $\mathrm{HHO}$ gas supplied to the engine gives an average $\mathrm{CO}$ reduction of $53 \%$. The area of the electrode plates influences the optimal presence of $\mathrm{O}_{2}$ gas, distance and number of electrode plates. The increase of $\mathrm{O}_{2}$ supplied by the $\mathrm{HHO}$ gas generator has reduced the $\mathrm{CO}$ release 
content to $1.78 \%$. Which is optimal, then the $\mathrm{O}_{2}$ gas supplied has the role of converting $\mathrm{CO}$ gas to $\mathrm{CO}_{2}$, an additional $14.8 \%$.

(iii) The incomplete combustion of the mixing fuel in the engine combustion chamber has produced $\mathrm{HC}$ gas emissions. The presence of increased $\mathrm{O}_{2}$ in the fuel complex mixture has resulted in incomplete combustion. This situation has reduced $\mathrm{HC}$ release by $57 \%$.

\section{Acknowledgement}

The authors would like to express their appreciation to Universiti Sultan Zainal Abidin Malaysia and the Ministry of Higher Education Malaysia for providing financial support for this work through a research grant (FRGS/1/2015/TK10/JPP/03/1).

\section{References}

[1] Change, IPCC Climate. "Synthesis Report. Contribution of working groups I." II and III to the Fifth Assessment Report of the Intergovernmental Panel on Climate Change 151, no. 10.1017 (2014).

[2] Kahveci, Elif Eker, and Imdat Taymaz. "Experimental study on performance evaluation of PEM fuel cell by coating bipolar plate with materials having different contact angle." Fuel 253 (2019): 1274-1281. https://doi.org/10.1016/i.fuel.2019.05.110

[3] Taymaz, Imdat, and Merthan Benli. "Emissions and fuel economy for a hybrid vehicle." Fuel 115 (2014): $812-817$. https://doi.org/10.1016/i.fuel.2013.04.045

[4] Yusof, Siti Nurul Akmal, Abreeza Manap, Nurfanizan Mohd Afandi, Musdalilah Salim, and Halina Misran. "Mechanical and wear properties of aluminum coating prepared by cold spraying." In AIP Conference Proceedings, vol. 1669, no. 1, p. 020044. AIP Publishing LLC, 2015. https://doi.org/10.1063/1.4919182

[5] Davies, John, Michael Grant, John Venezia, and Joseph Aamidor. "Greenhouse gas emissions of the US transportation sector: Trends, uncertainties, and methodological improvements." Transportation Research Record 2017, no. 1 (2007): 41-46. https://doi.org/10.3141/2017-06

[6] Shaheen, Susan A., and Timothy E. Lipman. "Reducing greenhouse emissions and fuel consumption: Sustainable approaches for surface transportation." IATSS Research 31, no. 1 (2007): 6-20. https://doi.org/10.1016/S0386$1112(14) 60179-5$

[7] Yusof, Siti Nurul Akmal, Yutaka Asako, Mohammad Faghri, Lit Ken Tan, and Nor Azwadi bin Che Sidik. "Numerical analysis for irreversible processes in a piston-cylinder system." International Journal of Heat and Mass Transfer 124 (2018): 1097-1106. https://doi.org/10.1016/j.ijheatmasstransfer.2018.04.008

[8] Yusof, Siti Nurul Akmal, Yutaka Asako, Mohammad Faghri, Lit Ken Tan, Nor Azwadi bin Che Sidik, and Wan Mohd Arif bin Aziz Japar. "Numerical analysis of irreversible processes in a piston-cylinder system using LB1S turbulence model." International Journal of Heat and Mass Transfer 136 (2019): 730-739. https://doi.org/10.1016/i.ijheatmasstransfer.2019.03.007

[9] Radhakrishnan, Santhanakrishnan, Dinesh Babu Munuswamy, Yuvarajan Devarajan, and Arulprakasajothi Mahalingam. "Performance, emission and combustion study on neat biodiesel and water blends fuelled research diesel engine." Heat and Mass Transfer 55, no. 4 (2019): 1229-1237. https://doi.org/10.1007/s00231-018-2509-x

[10] Yusof, Siti Nurul Akmal, Nor Azwadi Che Sidik, Yutaka Asako, Wan Mohd Arif Aziz Japar, Saiful Bahri Mohamed, and Nura Mu'az Muhammad. "A comprehensive review of the influences of nanoparticles as a fuel additive in an internal combustion engine (ICE)." Nanotechnology Reviews 9, no. 1 (2020): 1326-1349. https://doi.org/10.1515/ntrev-2020-0104

[11] Sazali, Norazlianie. "A Short Review on Developing Technologies by Hydrogen." Journal of Advanced Research in Materials Science 59, no. 1 (2019): 14-23.

[12] Taib, Norhidayah Mat, Mohd Radzi Abu Mansor, and Wan Mohd Faizal Wan Mahmood. "Simulation of Hydrogen Fuel Combustion in Neon-oxygen Circulated Compression Ignition Engine." Journal of Advanced Research in Numerical Heat Transfer 3, no. 1 (2020): 25-36.

[13] Brown, Yull. "Welding." U.S. Patent 4,014,777, filed July 19, 1974, and issued March 29, 1977.

[14] Polverino, Pierpaolo, Federica D'Aniello, Ivan Arsie, and Cesare Pianese. "Study of the energetic needs for the onboard production of Oxy-Hydrogen as fuel additive in internal combustion engines." Energy Conversion and Management 179 (2019): 114-131. https://doi.org/10.1016/i.enconman.2018.09.082

[15] Ji, Changwei, and Shuofeng Wang. "Experimental study on combustion and emissions characteristics of a spark ignition engine fueled with gasoline- hydrogen blends." Energy \& Fuels 23, no. 6 (2009): 2930-2936. https://doi.org/10.1021/ef900209m 
[16] Kazim, Ali Hussain, Muhammad Bilal Khan, Rabia Nazir, Aqsa Shabbir, Muhammad Salman Abbasi, Hamza Abdul Rab, and Nabeel Shahid Qureishi. "Effects of oxyhydrogen gas induction on the performance of a small-capacity diesel engine." Science Progress 103, no. 2 (2020): 0036850420921685. https://doi.org/10.1177/0036850420921685

[17] Subramanian, Balaji, and Saleel Ismail. "Production and use of HHO gas in IC engines." International Journal of Hydrogen Energy 43, no. 14 (2018): 7140-7154. https://doi.org/10.1016/i.ijhydene.2018.02.120

[18] Huang, Zuohua, Yong Zhang, Qian Wang, Jinhua Wang, Deming Jiang, and Haiyan Miao. "Study on flame propagation characteristics of natural gas- hydrogen- air mixtures." Energy \& Fuels 20, no. 6 (2006): 2385-2390. https://doi.org/10.1021/ef060334v

[19] Kwasi-Effah, C. C., A. I. Obanor, and F. A. Aisien. "A review on electrolytic method of hydrogen production from water." American Journal of Renewable and Sustainable Energy 1, no. 2 (2015): 51-57.

[20] Shivaprasad, K. V., S. Raviteja, Parashuram Chitragar, and G. N. Kumar. "Experimental investigation of the effect of hydrogen addition on combustion performance and emissions characteristics of a spark ignition high speed gasoline engine." Procedia Technology 14 (2014): 141-148. https://doi.org/10.1016/i.protcy.2014.08.019

[21] Santilli, Ruggero Maria. "A new gaseous and combustible form of water." International Journal of Hydrogen Energy 31, no. 9 (2006): 1113-1128. https://doi.org/10.1016/i.ijhydene.2005.11.006

[22] Klein, Dennis, and Ruggero Santilli. "Apparatus and method for the conversion of water into a new gaseous and combustible form and the combustible gas formed thereby." U.S. Patent US 2006/0075683, filed November 15, 2005, and issued April 13, 2006.

[23] Falahat, A. M., M. A. Hamdan, and J. A. Yamin. "Engine performance powered by a mixture of hydrogen and oxygen fuel obtained from water electrolysis." International Journal of Automotive Technology 15, no. 1 (2014): 97-101. https://doi.org/10.1007/s12239-014-0011-0

[24] Aydin, Kadir, and Raif Kenanoğlu. "Effects of hydrogenation of fossil fuels with hydrogen and hydroxy gas on performance and emissions of internal combustion engines." International Journal of Hydrogen Energy 43, no. 30 (2018): 14047-14058. https://doi.org/10.1016/i.ijhydene.2018.04.026

[25] Negurescu, Niculae, Constantin Pana, and Alexandra Cernat. "Aspects of using hydrogen in SI engine." University" Politehnica" of Bucharest Scientific Bulletin, Series D: Mechanical Engineering 74, no. 1 (2012): 11-20.

[26] Ismail, Jailani, Martini Muhamad, Saiful Bahri Mohamed, Alias Mohd, Wan Noor Fatihah Mohamad, Zakaria Ibrahim, and Muhamad Ruzlan Musanih. "Down milling cutting parameters optimization utilizing the two level full factorial design approach." In Materials Science Forum, vol. 863, pp. 57-61. Trans Tech Publications Ltd, 2016. https://doi.org/10.4028/www.scientific.net/MSF.863.57

[27] Mohamed, Saiful Bahri, Wan Noor Fatihah Mohamad, Martini Muhamad, Jailani Ismail, Been Seok Yew, Alias Mohd, Zakaria Ibrahim, and Muhamad Ruzlan Musanih. "The effects of cutting parameters on surface texture of hybrid composite CFRP/AL2024." In Materials Science Forum, vol. 863, pp. 111-115. Trans Tech Publications Ltd, 2016. https://doi.org/10.4028/www.scientific.net/MSF.863.111

[28] Masjuki, H. H., A. M. Ruhul, Nirendra N. Mustafi, M. A. Kalam, M. I. Arbab, and IM Rizwanul Fattah. "Study of production optimization and effect of hydroxyl gas on a $\mathrm{Cl}$ engine performance and emission fueled with biodiesel blends." International Journal of Hydrogen Energy 41, no. 33 (2016): 14519-14528. https://doi.org/10.1016/j.ijhydene.2016.05.273

[29] El-Kassaby, Mohamed M., Yehia A. Eldrainy, Mohamed E. Khidr, and Kareem I. Khidr. "Effect of hydroxy (HHO) gas addition on gasoline engine performance and emissions." Alexandria Engineering Journal 55, no. 1 (2016): $243-251$. https://doi.org/10.1016/i.aej.2015.10.016

[30] Madyira, D., and Wayne G. Harding. "Effect of HHO on four stroke petrol engine performance." In 9th South African Conference on Computational and Applied Mechanics, pp. 14-16. 2014.

[31] Yilmaz, Ali Can, Erinç Uludamar, and Kadir Aydin. "Effect of hydroxy (HHO) gas addition on performance and exhaust emissions in compression ignition engines." International Journal of Hydrogen Energy 35, no. 20 (2010): 1136611372. https://doi.org/10.1016/i.ijhydene.2010.07.040

[32] Hakim, Abdul. "Karakterisasi untuk kerja generator gas HHO tipe Dry cell dengan elektroda titanium dan penambahan PWM." PhD diss., Institut Teknologi Sepuluh Nopember, 2016.

[33] De Silva, T. S., L. Senevirathne, and T. D. Warnasooriya. "HHO generator-an approach to increase fuel efficiency in spark ignition engines." European Journal of Advances in Engineering and Technology 2, no. 4 (2015): 1-7.

[34] Ozcanli, Mustafa, Mustafa Atakan Akar, Ahmet Calik, and Hasan Serin. "Using HHO (Hydroxy) and hydrogen enriched castor oil biodiesel in compression ignition engine." International Journal of Hydrogen Energy 42, no. 36 (2017): 23366-23372. https://doi.org/10.1016/j.ijhydene.2017.01.091

[35] Birtas, Adrian, Iulian Voicu, Cristian Petcu, Radu Chiriac, and Nicolae Apostolescu. "The effect of HRG gas addition on diesel engine combustion characteristics and exhaust emissions." International Journal of Hydrogen Energy 36, no. 18 (2011): 12007-12014. https://doi.org/10.1016/j.ijhydene.2011.06.015 
[36] Baltacioglu, Mustafa Kaan, Hüseyin Turan Arat, Mustafa Özcanli, and Kadir Aydin. "Experimental comparison of pure hydrogen and HHO (hydroxy) enriched biodiesel (B10) fuel in a commercial diesel engine." International Journal of Hydrogen Energy 41, no. 19 (2016): 8347-8353. https://doi.org/10.1016/j.ijhydene.2015.11.185

[37] Ozgur, Tayfun, Erdi Tosun, Ceyla Ozgur, Gökhan Tuccar, and Kadir Aydın. "Numerical studies of engine performance, emission and combustion characteristics of a diesel engine fuelled with hydrogen blends." In Advanced Materials Research, vol. 1016, pp. 582-586. Trans Tech Publications Ltd, 2014. https://doi.org/10.4028/www.scientific.net/AMR.1016.582

[38] Mazloomi, Kaveh, Nasri B. Sulaiman, and Hossein Moayedi. "Electrical efficiency of electrolytic hydrogen production." International Journal of Electrochemical Science 7, no. 4 (2012): 3314-3326.

[39] Jumiati, Joko Sampurno, Irfana Diah Faryuni, and Joko Sampurno. "Pengaruh Konsentrasi Larutan Katalis dan Bentuk Elektroda dalam Proses Elektrolisis untuk Menghasilkan Gas Brown." POSITRON 3, no. 1 (2013). https://doi.org/10.26418/positron.v3i1.4757

[40] Uludamar, Erinç, Erdi Tosun, Gökhan Tüccar, Şafak Yıldızhan, Ahmet Çalık, Sefa Yıldırım, Hasan Serin, and Mustafa Özcanlı. "Evaluation of vibration characteristics of a hydroxyl $(\mathrm{HHO})$ gas generator installed diesel engine fuelled with different diesel-biodiesel blends." International Journal of Hydrogen Energy 42, no. 36 (2017): 23352-23360. https://doi.org/10.1016/i.ijhydene.2017.01.192

[41] Calo, J. M. "Comments on "A new gaseous and combustible form of water," by RM Santilli:(Int. J. Hydrogen Energy 2006: 31 (9), 1113-1128)." International Journal of Hydrogen Energy 32, no. 9 (2007): 1309-1312. https://doi.org/10.1016/j.ijhydene.2006.11.004 